University of Chicago Law School

Chicago Unbound

Journal Articles

Faculty Scholarship

1944

\title{
Trial Court's Freedom of Discretion in Sentencing After Revocation of Probation
}

Ernst W. Puttkammer

Follow this and additional works at: https://chicagounbound.uchicago.edu/journal_articles

Part of the Law Commons

\section{Recommended Citation}

Ernst W. Puttkammer, Comment, "Trial Court's Freedom of Discretion in Sentencing After Revocation of Probation," 11 University of Chicago Law Review 286 (1944).

This Article is brought to you for free and open access by the Faculty Scholarship at Chicago Unbound. It has been accepted for inclusion in Journal Articles by an authorized administrator of Chicago Unbound. For more information, please contact unbound@law.uchicago.edu. 


\section{COMMENT AND CASE NOTES}

\section{THE TRIAL COURT'S FREEDOM OF DISCRETION IN SENTENCING AFTER REVOCATION OF PROBATION}

E. W. PutTKamareR*

In Roberts $\mathrm{v}$. United States ${ }^{\mathrm{I}}$ the question at issue was whether under the federal Probation Act $^{2}$ a trial court which had imposed and then suspended a sentence and placed the defendant on probation, could later revoke the probation and impose a new and more severe sentence. In the original proceedings the defendant (who then could have been sentenced to a three-year prison term) received a two-year term but was released on probation. Subsequently the probation was revoked and a new sentence of three years was imposed. The pertinent provision in the statute provides that "the court may revoke the probation or the suspension of sentence, and may impose any sentence which might originally have been imposed." In a divided decision the majority of the United States Supreme Court held that the language of the statute did not mean that any sentence which originally might have been imposed could now be imposed but that on the contrary only the original sentence could be imposed. $\mathrm{Mr}$. Justice Black delivered the majority opinion, while the Chief Justice and Mr. Justice Reed concurred with Mr. Justice Frankfurter in his dissenting opinion.

At first glance it would certainly seem that the language of the statute ("any sentence which might originally have been imposed") did not deprive the trial court of all choice. The majority in reaching a contrary conclusion rests largely on the history of the statute. Prior to its enactment two different approaches to the probation problem were already clearly recognized. One advocated confronting the probationer with a fixed, definite threat which would not be modified, should he later misbehave. The other favored flexibility, not only at the time of trial but also later when probation was revoked. The respective arguments for and against these two positions will be considered later. The only point im-

\footnotetext{
* Professor of Law, University of Chicago.

I 64 S. Ct. II3 (I943).

2 U.S.C. Title I8, sec. 725, I8 U.S.C.A., sec. 725 . 
portant at the moment is that these two approaches were definitely known at the time when the act was passed. The Court devotes considerable space to showing that Congress was aware of the difference, and then concludes that the language adopted constitutes an acceptance of the former view. No attempt is made to square this with the statute's "any sentence." Likewise there is no attempt to meet the argument that the use of such broad language by Congress is more, not less, significant in the light of awareness of the two schools of thought on the subject. The principal authority relied on is an opinion by the Attorney General in I930 which held that under a statute permitting the President to drop from the Navy any officer who had been "finally sentenced" to the penitentiary, it was not any the less a "final sentence" to the penitentiary even though execution was suspended and probation was granted. The Attorney General went on to express a doubt as to whether, in the event of revocation of probation, a new and different sentence could be imposed, but gave no reason for his doubt ${ }^{3}$ and immediately followed this remark with a statement that it was in no wise necessary to pass on that point, so far as the matter then before him was concerned. The Supreme Court then refers to the Attorney General's Survey of Release Procedures. ${ }^{4}$ The passage in question does state that "it would seem that when the suspension of execution is revoked the original sentence becomes operative," citing as only authority, however, the Attorney General's opinion just referred to and going on immediately to say that no cases of a later, increased sentence had been found but that if any such should be found certain questions of constitutionality might arise. With this there can of course be no quarrel. Where probation has been revoked, of course the original sentence becomes operative if the trial court does not attempt to modify it. The question is as to the power of the trial court to modify under the language of the statute. That language is not any the less clear because by giving it its natural effect certain new problems may be raised.

The only other authorities dealing with the present point which are cited, are four subordinate federal decisions, two cited in the opinion and two in a footnote. The two former give us little aid, although, as the opinion recognizes, what bearing they have is directly opposed to the present case, not in support of it. In one, United States v. Moore, ${ }^{5}$ increased sentence was imposed, the power of the court to do so being assumed with-

3 Beyond saying, "If it had been the intention to create such an important power, it would seem that more explicit language would have been used." 36 Op. Attys. Gen. 186 at r92.

4 Published in I939. The reference is to vol. $x$, p. I3.

5 ror F. 2 d 56 (C.C.A. $5^{\text {th }}$ I939). 
out discussion. In the other, Reimer v. Regan ${ }^{6}$ the same power was exercised, the defendant conceding that the court was authorized so to do. In both of the footnote cases, however, the power of the court to impose a different sentence was directly contested and was expressly upheld. It is true that in both the new sentence imposed less punishment than the original sentence had called for, and in one of the cases, United States v. Antinori, ${ }^{7}$ the court expressly pointed out that it was not being called on to decide whether a sentence might be increased. In the other, however, Scalia v. United States, ${ }^{8}$ the trial court's power to change the sentence under the statute was sweepingly recognized without any reference being made to the direction of the change. Nor is it wholly easy to see how the nature of the proposed change can determine the power of a court to make it. The majority opinion carefully confines itself to an attempted increase in punishment and thereby raises the inference that it might adopt a different view in the event of a contested decrease, but it gives no hint as to the basis for such a difference.

As a final word on the legal authorities reference might be made to Korematsu v. United States, ${ }^{9}$ decided less than six months earlier and likewise through the mouth of Mr. Justice Black, in which it was expressly stated that "the difference to the probationer between imposition of sentence followed by probation .... and suspension of the imposition of sentence .... is one of trifling degree." It is somewhat surprising to find this "trifling" difference so soon thereafter made a matter of great importance in a situation where, to say the least, such a decision was not needed. ${ }^{10}$

${ }^{6}{ }_{104}$ F. 2 d 704 (C.C.A. 9th I939), cert. den., 308 U.S. 553, 60 S. Ct. 105 (1939).

${ }^{7} 59$ F. 2 d 17 I (C.C.A. $5^{\text {th }}$ 1932).

862 F. $2 d 220$ (C.C.A. Ist 1932).

${ }^{9}{ }_{319}$ U.S. 432 at 435,63 S. Ct. II 24 at ri26.

ro The same section of the statute was considered by the court in Cornerz v. United States, 69 F. 2 d 965 (C.C.A. 5th 1934). Although a different problem was involved, the court's comments on the statute are of present interest. In $\times 93^{\circ}$ the defendant was sentenced to serve a year and a day, but sentence was suspended and he was put on probation for five years. On January 25, I933, probation was revoked and "the sentence heretofore imposed herein reinstated in full force and effect." It was now necessary to determine whether the defendant was serving under a sentence dated I930 or January 25, I933. The court said, "The power of making a new sentence applies as well to a case in which a sentence was imposed and suspended for probation as to one in which probation was ordered without imposition of sentence. United States v. Antinori (C.C.A.) 59 F. (2d) I 7 r. In the present case the old sentence was reinstated instead of making another essentially different, but the power exercised in either case is that given by the words quoted from the statute. The old sentence became effective because the court on January 25, I933, so adjudged. Otherwise it would have remained a dead letter. If appellant is now to be imprisoned, it is not directly by virtue of the old sentence, but by virtue of the judgment of Jamuary 25, 1933" (italics supplied). This passage was quoted with approval in Greenhaus v. Sanford, 37 F. Supp. 644 (D.C.N.D. Ga. r94I). 
If the majority opinion's analysis of the law is unconvincing, it can be said that the desirability of the practical consequences of the decision are fully as open to doubt. The principal values which the imposition of a fixed and unchangeable sentence prior to probation are sometimes assumed to have are, first, that a definite and specific prison term staring a prisoner in the face is a more effective deterrent of violation of probation than is a prison sentence, the length of which has not yet been irrevocably determined, and, second, that imposition of sentence prior to probation is more economical, since the original sentence may be imposed, in the event of violation of probation, without consideration of anything except the fact of violation of probation. If these values are to be realized, it becomes essential that the original sentence be executed when probation is violated.

On the other hand, the principal value of the reservation of final decision as to the amount of punishment until probation has been violated is that it leaves the court free to utilize all available knowledge regarding the offender at the time of execution of sentence, including knowledge regarding him obtained while on probation. Furthermore, it cannot be demonstrated that this method is less economical or less effective as a deterrent of violation of probation than is the unchangeable sentence imposed prior to probation.

The argument for reservation of final decision until probation has been violated is decidedly more weighty. Indeed it might well be argued that Congress should not even have authorized the mere suspension of a fixed sentence, and that the courts should not use this method, even if authorized by Congress. The naming of any definite sentence, even if, contrary to the present decision, it may later be departed from, does in fact tend to tie the hands of the court at the time that probation is revoked, and so makes it unable to use later-obtained knowledge regarding the offender. The court's hands would be tied, first, by the almost universal custom of executing the sentence as originally imposed, and, second, by the feeling of injustice created in the offender if the original sentence is increased. A modification of the original sentence in the form of a decrease of the prison term is quite as inconsistent with logic, except as to the argument regarding the feeling of injustice, as is a modification in the form of an increase. And, to quote the able dissenting opinion,, "We certainly should not countenance the notion that a probationer has a vested interest in the original sentence nor encourage him to weigh the length of such a sentence against any advantages he may find in violating his probation."

I At p. II8. 


\section{The whole case against the majority opinion is effectively summed up in the following quotation from the dissenting opinion: ${ }^{: 2}$}

The only practical result of the strained reading of the powers of the district courts by the decision today may well lead trial judges generally to place probationers on probation without any tentative sentence. A construction which leads to such a merely formal result, one so easily defeated in practice, should be avoided unless the purpose, the text and the legislative history of the Act converge toward it. The policy of probation clearly counsels against it, and neither the words of the Act nor their legislative history contradict that policy..$^{23}$

12 At p. Irg.

${ }^{23}$ Because the case under discussion turns so largely on the construction of a federal statute, no attempt has been made to consider in the text any state court decisions on the general point of a trial court's power to alter or modify a previously imposed sentence after revocation of probation. It is a matter of distinct surprise to find how rarely the question has had to be considered. Only the cases cited below were found which directly or indirectly dealt with the matter.

In People v. Stone, 25 N.Y.S. ad 94 (1940), the court held, under a statute providing that the court "may impose such sentence or make such commitment as might have been made at the time of conviction," that there was "no real distinction between the power to suspend sentence or to suspend execution of sentence," as "they are essentially one and the same" (citing four earlier New York cases as so holding) and "it follows, therefore, that the court may in the exercise of its discretion decrease the original term of punishment [citing People ex rel. Pringle v. Livingston, I35 Misc. 475, 239 N.Y. Supp. I22 (r930)]. The court also has discretion to increase the term. The language [of the statute] can admit of no other construction."

In Ex parte Goetz, II7 P. $2 d 47$ (D.C. App., Calif. I94I) there is a dictum that where probation is granted after sentence, the latter may be "modified" or set aside. The remark is not amplified, however, and was not called for, nor is there any statement as to what the word "modified" includes.

The scarcity of cases dealing with modified sentences can, however, be readily explained. Where the sentence is decreased the defendant is usually content to leave well enough alone, since the alternative generally would be his receiving the original sentence, and the state ordinarily cannot (and if it could, probably would not) contest the reduction. The scarcity of cases involving increased punishment is undoubtedly due to the infrequency with which courts take the step of increasing terms of imprisonment. 